sciendo Порівняльна професійна педагогіка 9(1)/2019 Comparative Professional Pedagogy 9(1)/2019

DOI: $10.2478 /$ rpp-2019-0009

$\mathrm{PhD}$ in Pedagogy, Senior Lecturer, IHOR ROSKVAS

Khmelnytskyi National University

Address: 11 Instytutska St., Khmelnytskyi, 29016, Ukraine

E-mail: ihor219115@gmail.com

\title{
CONCEPTUAL ASPECTS OF PROFESSIONAL TRAINING FOR ENGLISH LANGUAGE TEACHERS: THE UK EXPERIENCE
}

\begin{abstract}
The article deals with the problem of conceptual aspects of professional training for English language teachers in the UK. It is found that many curricula of British universities are based on the technology and procedure of exclusively professional training of future specialists, whereas general scientific and additional intellectual training is incorporated into extracurricular activities as proved by the ratio of study time allocated to different courses. Humanities and social sciences courses provide students with fundamental knowledge and the ability to navigate in the ever-growing volume of scientific knowledge, possibility and knowledge of social interaction. General professional and specialist courses cultivate professional mastery of future specialists and the ability to express, if necessary, professional mobility. It is clarified that English is a broad subject, which comprises three complementary elements studied either separately or combined. They are the following: English Literature (interpretation and analysis of literary texts and study of the history and theory of literature), English Language (the study of spoken, written and multimodal communication, their historical development and their distinctive levels of analysis: phonology, grammar and lexis) and creative writing (the practice of writing, the study of the literary and cultural contexts of writing and the exploration of the relationships that writing generates between writer, publisher, text and audience). It is concluded that professional training of English language teachers in the UK is based on conceptual aspects of such principles as neobehaviourism, liberalism, progressivism, social reconstructivism, cognitivism and humanism.
\end{abstract}

Keywords: professional training, English language, English language teachers, university, concept, aspect, the UK.

\section{АНОТАЦЯ}

У статті розглянуто проблему концептуальних аспектів професійної підготовки вчителів англійської мови у Великій Британії. Встановлено, що більшість освітніх програм у британських університетах трунтується на технології та прочедурі виключно професійної підготовки майбутніх фахівиів, тоді як загальнонаукові та додаткові інтелектуальні тренінги включено до позакласної діяльності, що підтверджується співвідношенням навчального часу, запланованого для різних дисииплін. Гуманітарні та соиіальні дисиипліни надають студентам фундаментальні знання $і$ вміння орієнтуватися в постійно зростаючому обсязі наукових знань, можлливостей $і$ знань соиіальної взаємодії. Загальнопрофесійні та спеціалізовані дисиипліни розвивають професійну майстерність майбутніх фахівиів і здатність до професійної мобільності. 3'ясовано, що спеиіальність "Англійська мова" є надзвичайно широкою і складається $з$ трьох допоміжних елементів, які вивчаються окремо або разом. Вони охоплюють 
sciendo Порівняльна професійна педагогіка 9(1)/2019 Comparative Professional Pedagogy 9(1)/2019

англійську літературу (інтерпретація та аналіз літературних текстів та вивчення історії та теорії літератури), англійську мову (вивчення усного, письмового та мультимодального спілкування, їхній історичний розвиток та відмінні рівні аналізу: фонологія, граматика та лексика) та творчу діяльність (практика письма, вивчення літературних та культурних контекстів письма, тощо). Зроблено висновок, що професійна підготовка вчителів англійської мови у Великій Британії базується на концептуальних аспектах таких принципів, як необіхевіоризм, лібералізм, прогресивізм, сочіальний реконструктивізм, когнітивізм та гуманізм.

Ключові слова: професійна підготовка, англійська мова, вчитель англійської мови, університет, концепція, аспект, Велика Британія.

\section{INTRODUCTION}

New approaches to the problem of quality of higher education and specialist training in the UK, similar to those being implemented in Ukraine, were introduced in the early 1990s after the adoption of Further and Higher Education Act (1992). The Act determined not only the strategy for developing higher education in the country but also formulated the ways and mechanisms for improving the quality of specialist training in the UK. In accordance with the law, the binary system of higher education opposing classical universities to polytechnic colleges was eliminated. They adopted a single model of higher education that is universities. Most polytechnics were awarded the status of universities and some of them shifted their orientation towards further education providing their graduates with secondary vocational education.

Nowadays, the UK universities are entitled to determine conceptual aspects of specialist training relying only on the recommendations of the Department for Education and framework instructions, QAA recommendations, etc. British scholars believe that the quality of specialist training implies the correspondence of the level of knowledge, skills and practical training to the adopted requirements and standards. Therefore, the quality of higher education is viewed as the indicators of the level of knowledge, abilities, skills and professional mastery of graduates to "state education standards" implemented in Ukraine. Under the conditions of university autonomy, there is no single legal framework and state regulations of higher education content, as well as unified requirements for graduates since every university adopts and implements its own degree programmes, the organization of the education process and assessment of student progress.

In view of reforming Ukranian higher education, especially after the adoption of the Laws of Ukraine "On Higher Education" (2014) and "On Education", it is crucial to continue studying British experience, especially in the context of formulating conceptual aspects of professional training for English language teachers.

\section{THE AIM OF THE STUDY}

The current research aims to study conceptual aspects of professional training for English language teachers in the UK.

\section{THEORETICAL FRAMEWORK AND RESEARCH FRAMEWORK}

Based on theoretical analysis, individualization and systematization of relevant sources, it is found that many curricula of British universities are based on the technology and procedure of exclusively professional training of future specialists, whereas general scientific and additional intellectual training is incorporated into extracurricular activities as proved by the ratio of study time allocated to different courses. Depending on the profile of 
professional training, general professional and specialist courses are allocated $50-80 \%$ of total study time and are of rather pragmatic nature. Humanities and social sciences courses provide students with fundamental knowledge and the ability to navigate in the evergrowing volume of scientific knowledge, possibility and knowledge of social interaction. General professional and specialist courses cultivate professional mastery of future specialists and the ability to express, if necessary, professional mobility (Baskerville, MacLeod, \& Saunders, 2013).

Special attention should be also paid to the qualification characteristic of lecturers. Professional activities of lecturers require that they should be able to engage in teaching and research activities. It is preferable that they have a doctoral degree $(\mathrm{PhD})$. In the $\mathrm{UK}$, the lecturer should know and be able to do the following:

1) have a profound knowledge of the subject they teach;

2) combine teaching, research and administrative activities;

3) establish interaction with students, postgraduate students and colleagues;

4) conduct practical classes and lectures, experiments, fieldwork;

5) supervise student placements;

6) organize and conduct workshops, seminars, tutorials, discussions;

7) provide counselling (employment, studies, personal matters, etc.);

8) objectively evaluate student progress and help them achieve greater results;

9) conduct exams and ask clear and objective questions;

10) think analytically and critically;

11) participate in professional associations, communities, clubs, societies, etc.;

12) have good communication skills;

13) have a high-level practical competency and demonstrate it when working with students in small and big groups;

14) strive for professional and personal development (Knight, \& Yorke, 2004).

As shown by Subject Benchmark Statement for English (2015) developed by QAA, equality and diversity should be ensured throughout professional training of specialists since it is necessary to promote equal dignity and worth of every student and support achievements for students with diverse requirements, backgrounds and entitlements (QAA, 2015).

It must be noted that British educators focus more on the role and value of English within culture and society considering the growing impact of English in the international scope. Indeed, English is a core academic subject, which covers the study on structure, history and use of the English language, as well as critical analysis of texts written in English. It rather contributes to the development of English cultural life and promotes its significance in the context of international studies.

Thus, the following section of the research aims to disclose conceptual aspects of professional training of English language teachers in the UK.

\section{RESULTS}

According to studies, with regard to those undergraduates enrolled for Single Honours English, the number of full-time students on a course ranges from 23 to 700, with the number of part-time students ranging from 1 to 210. In terms of numbers of full-time students enrolled on a Combined Honours English, the figures range from 1 to 700 , and about half of all undergraduates reading English do so in tandem with studying another subject, as part of Combined Honours or Joint Honours programmes. English is also a central subject in most modular schemes in the humanities, which allow students to choose from a 
sciendo Порівняльна професійна педагогіка 9(1)/2019 Comparative Professional Pedagogy 9(1)/2019

range of different modules or units within an overall suite of humanities subjects (including history, women's studies, English studies, writing, American studies or religious studies) (Childs, 2008, p. 11).

The Subject Benchmark Statement for English states that English is a broad subject, which comprises three complementary elements studied either separately or combined. They are the following: English Literature (interpretation and analysis of literary texts and study of the history and theory of literature), English Language (the study of spoken, written and multimodal communication, their historical development and their distinctive levels of analysis: phonology, grammar and lexis) and creative writing (the practice of writing, the study of the literary and cultural contexts of writing and the exploration of the relationships that writing generates between writer, publisher, text and audience) (QAA, 2015).

Given the achievements of the humanities, namely, culturology, linguistics, linguistics, psycholinguistics, British scholars indicate that under modern conditions a substantiated cognitive communicative paradigm of understanding languages and linguistic activity of future English language teachers has been formed. It is based on the multidimensional language system associated with the dynamics of the cognitive processes of human thinking. Thus, anthropocentric, cognitive, conceptual description of the language is provided to the foreground to ensure the perfect communication with representatives of native / non-native culture. Professional activity of English languages teachers covers the multi-valued interaction of subjects of communication, which requires from them an ability to directly understand the sociocultural meanings of linguistic units of the English language. It is no coincidence that the concept of "linguistic personality" acquires a special significance, and in the context of professional language proficiency - "a professional linguistic personality" (Bowskill, 2010; Gomez-Cash, 2016; James, 1999).

The content of professional training for English language teachers must be consistent with the principles of modular design in the context of the multidisciplinary intercultural interaction; the relevant needs of the real labour market; inclusion, methods of productive activity, intuitive and creative exercises and emotional intellectual proficiency, etc. (Lugea, 2016).

R. Hudson $(1983 ; 2004 ; 2007)$ states that professional training of language teachers should be based on the main trends of higher education, in particular the integration and globalization processes. It must also meet modern linguistic challenges designed in the context of interdisciplinary linguistics that is rather important and qualitatively influences the development of the English language worldwide.

The content of professional training for English language teachers is organically combined with the programmatic learning outcomes, which in turn are presented in the form of competencies and competences providing for the acquisition of certain skills and abilities. S. Lester (2014) is convinced that at the present stage of education development English language teachers must have relevant knowledge required for professional activities, be able to implement creative approach to professional activity and possess such personal qualities as tact, emotional balance, individuality, independence.

According to M. Bray, B. Adamson \& M. Mason (2007), professional competency of English language teachers is of paramount importance since its foundation is laid in during studying at higher education institutions. However, its further level can only grow in the course of professional (linguistic, teaching) activity with the use of innovative technologies, as required by modern changes in education. Tracing this internal dynamics 
8 sciendo Порівняльна професійна педагогіка 9(1)/2019 Comparative Professional Pedagogy 9(1)/2019

means to evaluate professional competency of English language teachers and predict their professional growth.

\section{CONCLUSIONS}

The conducted research proves that considering modern requirements for further development of the European Higher Education Area towards which the Ukrainian system of higher education strives, professional linguistic and professional pedagogical competency of English language teachers are defined as the leading criteria of higher education quality in the field of foreign languages recognized by the European pedagogical community, including the UK. Modern foreign and Ukrainian systems of higher education need competitive specialists who have well-developed research skills, are able to independently master new knowledge, develop their abilities to a high level of self-control and selfevaluation. In the UK, professional training of English language teachers is based on conceptual aspects of such principles as neobehaviourism, liberalism, progressivism, social reconstructivism, cognitivism and humanism. These principles should be implemented into the system of professional training for English language teachers in Ukraine.

Prospects for further studies include studying technological aspects of professional training for English language teachers in the developed countries.

\section{REFERENCES}

1. Baskerville, S., MacLeod, F., \& Saunders, N. (2013). A guide to UK higher education and partnerships for overseas universities, UK Higher Education International and Europe Unit. Retrieved from http://www.international.ac.uk/media/23468 32/guide-to-uk-he-and-partnerships_web_final.pdf.

2. Bray, M., Adamson, B., \& Mason, M. (2007). Comparative education research. Approaches and methods. Hong Kong: Springer.

3. Bowskill, S. (2010). Guest editorial: considering postgraduate study in languages, linguistics and area studies? Debut: the Undergraduate Journal of Languages, Linguistics and Area Studies, 1 (2), 45-47.

4. Childs, P. (2008). The essential guide to English studies. London: Continuum.

5. Gomez-Cash, O. (2016). Professional contexts for modern languages: work experience and academic reflection in a multilingual context. In E. Corradini, K. Borthwick \& A. Gallagher-Brett (Eds.), Employability for Languages: a Handbook (pp. 57-66). Dublin: Research-publishing.net.

6. Hudson, R. (1983). Linguistic equality (CLIE Working Paper 1). London: Committee for linguistics in education.

7. Hudson, R. (2004). Why education needs linguistics (and vice versa). Journal of linguistics, 40, 105-130.

8. Hudson, R. (2007). How linguistics has influenced schools in England. Language \& linguistics compass, 1, 227-242.

9. James, C. (1999). Language awareness: implications for the language curriculum. Language, Culture and Curriculum, 12, 94-115.

10. Knight, P., \& Yorke, M. (2004). Learning, curriculum and employability in higher education. London: Routledge Falmer.

11. Lester, S. (2014). Professional standards, competence and capability. Higher Education, Skills and Work-Based Learning, 4 (1), 31-43. 
12. Lugea, J. (2016). Language in the workplace: combining academic study with work experience. In E. Corradini, K. Borthwick \& A. Gallagher-Brett (Eds.), Employability for Languages: a Handbook (pp. 17-24). Dublin: Research-publishing.net.

13. QAA. (2015). Subject Benchmark Statement for English. Retrieved from https://www.qaa.ac.uk/docs/qaa/subject-benchmark-statements/sbs-english15.pdf? sfvrsn=4f9df781_12\%5D.

14. Staffordshire University. (2015). Survival guide to teaching in higher education. Teach well - an introductory guide. Retrieved from http://blogs.staffs.ac.uk/adublog/files/ 2015/09/Teach-Well-An-introductory-guide-to-teaching-in-higher-education-2015.pdf.

15. Walmsley, J. (2008). “... a term of opprobrium”: twentieth century linguistics and English philology. History of Linguistics 2008, Selected Papers from the Eleventh International Conference on the History of the Language Sciences (ICHoLS XI). Potsdam: Ed., G. Hassler; Benjamins: Amsterdam. 